\title{
Between Institutional Psychiatry and Mental Health Care: Social Psychiatry in The Netherlands, 1916-2000
}

\author{
HARRY OOSTERHUIS*
}

The term "social psychiatry" became current in the Netherlands from the late 1920s. Its meaning was imprecise. In a general way, the term referred to psychiatric approaches of mental illness that focused on its social origins and backgrounds. In this broad interpretation social psychiatry was connected to the psycho-hygienic goal of preventing mental disorders, but also to epidemiological research on the distribution of mental illness among the population at large. The treatment called "active therapy", introduced in Dutch mental asylums in the 1920s and geared towards the social rehabilitation of the mentally ill (especially through work), was also linked with social psychiatry. In a more narrow sense social psychiatry indicated what before the 1960s was usually called "after-care" and "pre-care": forms of medical and social assistance for patients who had been discharged from the mental asylum or who had not yet been institutionalized. This article focuses on the twentieth-century development of Dutch social psychiatry in this more narrow sense, without, however, losing sight of its wider context: on the one hand institutional psychiatry for the insane and on the other the mental hygiene movement and several outpatient mental health facilities, which targeted a variety of groups with psychosocial and behavioural problems. In fact, the vacillating position of pre- and after-care services was again and again determined by developments in these adjacent psychiatric and mental health care domains. This overview is chronologically divided into three periods: the period between and during the two world wars, when psychiatric pre- and aftercare came into being; the post-Second World War era until 1982, when the Social-Psychiatric Services expanded and professionalized; and the 1980s and 1990s, when they became integrated in community mental health centres.

\section{The Beginnings of Pre- and After-Care, 1916-1945}

Throughout the nineteenth century, psychiatry in the Netherlands primarily developed in relation to the care and treatment of the insane in asylums. Around 1900 psychiatry gained ground as a medical discipline at universities, in clinics that were tied to medical schools, in courts (forensic psychiatry), private practices, sanatoriums and other therapeutic facilities for mental and neurotic patients, and in centres for alcohol addiction. After the First World War, some psychiatrists increasingly treated individuals who had been certified as insane, but who were not or no longer hospitalized in an asylum. Already from the midnineteenth century, philanthropic associations had been established to offer material and

\footnotetext{
* Harry Oosterhuis, PhD, Department of History, University of Maastricht, PO Box 616, 6200 MD Maastricht, The Netherlands;

Harry.Oosterhuis@HISTORY.unimass.nl
}

I am indebted to Ton Brouwers for correcting my 


\section{Harry Oosterhuis}

social support for discharged patients. These organizations did not provide medical or psychiatric assistance. Around the First World War some psychiatrists advocated the necessity of social and psychiatric support for and supervision of the insane and mentally disturbed who were still living in society. The emergence of the first pre- and after-care facilities was also closely linked to the overcrowding of asylums and the growing costs of hospitalization. Between 1884 and 1915 the number of institutionalized patients almost tripled from about 4,800 to well over $14,000 .{ }^{1}$ The rising financial costs for local governments, who were responsible for the institutional care of those of little or no means as stipulated by the Poor Relief Law, and the increasing doubts about therapeutic possibilities caused psychiatrists and government officials to look for alternative care options.

The Amsterdam psychiatrist F S Meijers was instrumental in the birth of psychiatric preand after-care in the Netherlands when in 1916 he initiated the establishment of the city's health centre for nervous and psychological disorders. This public service provided help to discharged mental patients, as well as to mentally ill, feebleminded and other disabled individuals who had not yet been institutionalized. Seven years later, Meijers set up an association aimed not only at serving their social interests, but also at promoting his socialpsychiatric approach in other parts of the nation. In the 1920s and 1930s, psychiatrists, assisted by nurses, did consultations in some twenty Dutch towns and cities. ${ }^{2}$ Soon, however, it became clear that they could not meet the growing need for outpatient care for the mentally ill; moreover, it turned out, they were competing with other initiatives in this field. In the early 1920s the Jewish mental asylum of Apeldoorn opened an outpatient clinic in Amsterdam. This was the first social-psychiatric centre with direct ties to institutional psychiatry. Other mental institutions followed this example, the most successful being the pre- and after-care facility of Rotterdam's public asylum. This facility was based on a German model, that of the psychiatric institution in Erlangen, which offered social support to its discharged patients so as to prevent them from being hospitalized again. The Rotterdam outpatient facility, established in 1926 and staffed by a psychiatrist and several nurses, provided after-care to discharged patients and tried to prevent readmissions to the asylum by giving consultations, paying house visits and providing specific forms of care, mostly in close collaboration with poor relief services and other social organizations. ${ }^{3}$ The Rotterdam model was adopted by other Dutch mental institutions, such as the asylum in Leiden, where the psychiatrist H C Jelgersma argued that psychosis did not constitute a sufficient cause for hospitalization and that only patients whose behaviour was intolerable or dangerous needed to be certified as insane and hospitalized. ${ }^{4}$

\footnotetext{
${ }^{1} \mathrm{P}$ van der Esch, Geschiedenis van het staatstoezicht op krankzinnigen, Part 1, Leidschendam, Ministerie van WVC, 1975, pp. 81-2; J H Schuurmans Stekhoven, XXVste verslag van het staatstoezicht op krankzinnigen en krankzinnigengestichten over de jaren 1915-1929, 's-Gravenhage, Algemeene Landsdrukkerij, 1932, p. 172.

${ }^{2}$ Nederlandsche Vereeniging voor Geestelijke Volksgezondheid, Gids betreffende de geestelijke volksgezondheid (psychische hygiene) in Nederland, Amsterdam, F van Rossen, 1936, pp. 74-6.
}

\footnotetext{
${ }^{3}$ J F A Overbosch, 'De nazorg van geesteszieken door het gesticht in het grootestadsmilieu', Psychiatrische en neurologische bladen, 1928, 32: 17-25; J H Pameijer, 'Over voor- en nazorg voor geesteszieken', Tijdschrift voor sociale hygiëne, 1932, 34: 198-224.

${ }^{4} \mathrm{H}$ C Jelgersma, 'Voorzorg en nazorg van geesteszieken in de gemeente Leiden', Psychiatrische en neurologische bladen, 1930, 34: 87-91; idem, 'Problemen bij de Voorzorg en Nazorg van Geesteszieken', Psychiatrische en neurologische bladen, 1931, 35: 470-8.
} 


\section{Social Psychiatry in The Netherlands, 1916-2000}

The growth of pre- and after-care in the Netherlands during the 1930s, when about half of the country's thirty-nine mental institutions established outpatient facilities, was advanced by the endeavour of local and provincial governments to reduce expenditure on psychiatric patients. ${ }^{5}$ In a decade marked by economic depression, they were faced with tighter budgets and constantly rising numbers of admissions to mental asylums. Providing care for psychiatric patients in society was increasingly seen as a less expensive solution than institutionalization. The small-scale pre- and after-care facilities were supervised by psychiatrists, who kept office hours, but most of the work was carried out by nurses. They mobilized social support and paid house visits—a time-consuming job, especially in rural areas. Their activities were meant to allow mentally disturbed individuals to go on functioning longer in society. Another policy to serve this end was the establishment of sheltered workshops. However, given the uneven geographic spread of mental asylums and the religion-based identities of half of them, their outpatient facilities did not always operate effectively. In contrast to the few institutions that admitted patients on a regional basis only, as in Rotterdam, many catered for patients from their own religious constituency (Catholic, orthodox Protestant, Dutch Reformed or Jewish) generally from all over the country. The national catchment area, and the distances involved, made it difficult if not impossible to realize an intensive after-care programme, let alone a successful pre-care service. Effective pre-care and after-care required local or regional organization, and so cities and provinces began to establish facilities that operated more or less independently of the mental institutions. ${ }^{6}$

In the early 1930s the psychiatrist A Querido, Meijers' successor as director of Amsterdam's city mental health care facility, developed a comprehensive socialpsychiatric approach, which mandated psychiatrists and nurses to do a variety of tasks: keep office hours, offer crisis intervention, pay house calls, provide treatment based on medication, find alternatives to hospitalization, and serve as intermediary in case of a person's institutionalization. By visiting patients at home and devoting attention to the specific social circumstances that contributed to a specific mental problem's emergence, Querido tried to prevent the need for admission or readmission to institutions as much as possible, thus reducing the city's expenditure. Like Jelgersma, he believed that suffering from a mental disorder as such was no ground for hospitalizing individuals; rather, the issue was whether they could lead a more or less normal life despite their insanity and whether the social problems that were linked to it could be solved. ${ }^{7}$ Querido, who (not quite correctly) advertised himself as the pioneer of social psychiatry in the Netherlands, claimed that his approach was successful, at least in the sense that the number of admissions stabilized. Some other Dutch cities followed the example of Amsterdam by establishing public mental

\footnotetext{
${ }^{5}$ Nederlandsche Vereeniging voor Geestelijke Volksgezondheid, op. cit., note 2 above, pp. 67-74.

${ }^{6}$ Inspectie van het staatstoezicht op krankzinnigen en krankzinnigengestichten, Verslag van het staatstoezicht op krankzinnigen en krankzinnigengestichten over de jaren 1932-1936, The Hague, Algemeene Landsdrukkerij, 1938, p. 18; $\mathrm{T}$ van der Grinten, De vorming van de ambulante
}

geestelijke gezondheidszorg: Een historisch beleidsonderzoek, Baarn, Ambo, 1987, pp. 36-56.

${ }^{7}$ A Querido, 'Psychiatrie d'urgence', Nederlandsch Tijdschrift voor Geneeskunde, 1935, 79 (2): 124-34; idem, 'Ontwikkelingslijnen in de sociale psychiatrie', Psychiatrische en neurologische bladen, 1936, 40: 280-6; A J Heerma van Voss, 'Querido, een levensverhaal', Maandblad Geestelijke volksgezondheid, 1991, 46: 722-811. 


\section{Harry Oosterhuis}

health care services that operated independently of institutional psychiatry and that were paid for by local government. Elsewhere, new outpatient facilities were established on the basis of private and religious initiatives and longer-standing home nursing services. These received subsidies from provincial and local governments, who thus tried to justify a lowering of their subsidies to mental institutions. Basically, these facilities operated autonomously, without ties to mental hospitals. The Social-Psychiatric Services in Amsterdam and Rotterdam had a multiple staff and a clientele of some 1500 to 2000. But the others were fairly small, employing just one psychiatrist and a few nurses and serving not more than a few hundred patients each year. ${ }^{8}$

The aim to reduce spending constituted the major impetus for the development of social psychiatry, but it was made possible by the changing views on mental disease, as expressed by Jelgersma and Querido. Before the First World War a large gap existed between the mentally ill in institutions and society at large; insanity and mental health, it seemed, were two mutually exclusive categories. Social psychiatry began to develop only after the dichotomy between being normal and being mentally ill was qualified and institutions became more open. ${ }^{9}$ The 1904 and 1916 amendments to the Insanity Law of 1884 made it possible for the insane and patients with nervous disorders to be hospitalized exclusively on medical grounds, without judicial certification. This meant the undermining of the mental institution as a closed asylum. Moreover, psychoanalysis and phenomenological approaches prompted more interest in the psychic aspects of mental disease, and during the 1930s psychiatrists began to devote more attention to the social setting, not only as a factor that contributed to mental disorders, but also as "therapeutic environment", a function that was previously associated with mental asylums situated in rural areas. The introduction, in the 1920s, of "active therapy", as practised in Germany, also reflected the growing confidence in the possibility of making patients more responsible for their behaviour. This new didactic approach opened up opportunities for providing support to patients outside the institutions. Some psychiatrists viewed its beneficial effects as evidence of the major influence of the social environment on the behaviour of the mentally ill. ${ }^{10}$

In the 1930s pre- and after-care (or social psychiatry) became implicated in a border conflict between institutional psychiatry and the new and much broader domain of mental hygiene that had emerged from the middle of the 1920s. ${ }^{11}$ Not only psychiatrists, but also teachers, educational experts, sociologists, psychologists, criminologists, legal experts, and social workers were involved. Concerned about the perceived increase in mental and nervous disorders in modern society, they argued for a containment of this growth by taking preventive measures, an approach that had proved effective in the fight against

\footnotetext{
${ }^{8}$ Inspectie van het staatstoezicht op krankzinnigen en krankzinnigengestichten, op. cit., note 6 above, pp. 84-6.

${ }^{9} \mathrm{~N}$ de Boer, P Lips, J Megens and K in 't Veld, 'Van nazorg tot sociale psychiatrie: De opkomst van een ambulante psychiatriese zorg tegen de achtergrond van ontwikkelingen binnen de inrichtingen', Comenius, 1983, 3 (13): 69-84.

${ }^{10}$ Pameijer, op. cit., note 3 above, pp. 209-21; A Querido, 'Sociale Psychiatrie: Doel, Middelen
}

en Grenzen', Tijdschrift voor Sociale Geneeskunde, 1949, 14: 267-73, p. 267; W M van der Scheer, 'De beteekenis van het gesticht voor de Geestelijke Volksgezondheid', Psychiatrische en neurologische bladen, 1931, 35: 254-66.

${ }^{11} \mathrm{~L}$ de Goei, De psychohygïnisten. Psychiatrie, cultuurkritiek en de beweging voor geestelijke volksgezondheid in Nederland, 1924-1970, Nijmegen, SUN, 2001, pp. 15-68, 103-42. 


\section{Social Psychiatry in The Netherlands, 1916-2000}

epidemics and contagious diseases. The professional domain they claimed stretched from the care for socially disabled, feebleminded, psychopathic and insane individuals to the treatment of minor psychic flaws and behavioural problems of basically healthy people, and it included family-life, procreation, sexuality, education, alcoholism, crime, and leisure activities. The movement looked for inspiration to eugenics and pedagogy in particular. The theory of heredity and genetics, as well as the interventions based on it regarding procreation, supposedly offered opportunities for preventing mental defects. A new branch of pedagogy targeted "abnormal" and "retarded" children and sought to provide for early treatment and special educational programmes, so as to limit the occurrence of mental disorders among them at a later age.

Although many psychiatrists held that pre- and after-care naturally belonged to the new field of mental hygiene, this view was contested. Some eugenicists rejected the socialpsychiatric objective of keeping the mentally ill in society and outside mental asylums, because they felt that mentally disturbed individuals had to be prevented from procreating: apart from sterilization, social isolation by means of hospitalization in a closed institution provided the best guarantee for this. When it came to implementing concrete measures like sterilization and forced isolation, many social psychiatrists, however, proved sceptical of eugenics. Generally, they felt that therapeutic treatment and consideration for the patient's social setting provided the best prospects for countering mental afflictions, especially among young and acute patients. In social psychiatry, and in the psycho-hygienic movement as a whole, the confidence in the perfectibility of human beings, which in the Netherlands was strongly rooted in the tradition of moral education and social work, won out over biological determinism. Furthermore, Catholics and orthodox Protestants, whose views could not be ignored given the prominent social and institutional role of religious denominations in the Netherlands, also believed eugenics to be at odds with Christian principles. ${ }^{12}$

But a second and more important reason for the disputed relation between pre- and after-care and the mental hygiene movement was that some psycho-hygienists distanced themselves from the insane. In particular because of the social isolation and stigmatizing effect of asylums, they wanted to avoid the new field being associated with them. In 1928, on the initiative of E C Lekkerkerker, a lawyer, the first Dutch Child Guidance Clinic, geared towards troubled children and young delinquents, was established in Amsterdam. This new facility, although staffed by psychiatrists and psychiatric social workers, was rooted not so much in medical psychiatry as in the judicial domain, child welfare organizations, and the educational system. Stressing the hygienic aim of prevention, Lekkerkerker and her associates declared that efforts should focus in particular on maladjusted behaviour in children, and that therefore ordinary families were the main target of intervention. By applying a multidisciplinary approach - that of psychology and social work as well as of psychiatryand a psychoanalytic orientation, they sought to distance themselves from the institutional care of the insane, so as to avoid scaring off parents and educators.

The first Dutch initiatives in the area of psycho-hygiene were directly tied to the mental asylums' problems and largely based on eugenics and German social-psychiatric models. The Child Guidance Clinic, however, was adopted from the United States, where the mental

\footnotetext{
${ }^{12} \mathrm{~J}$ Noordman, Om de kwaliteit van het nageslacht: Eugenetica in Nederland
} 


\section{Harry Oosterhuis}

hygiene movement had changed its focus from the reform of institutional psychiatry and the prevention of mental disorders in adults to the treatment of children and their families on the basis of psychological insights. Because of Lekkerkerker's input and the participation of several leading Dutch psycho-hygienists in the First International Congress on Mental Hygiene in Washington in 1930, the Dutch movement increasingly tended towards the American model. This allowed a much more autonomous development of mental health care, disconnected from the institutional care of the insane and also from pre- and aftercare. ${ }^{13}$ Psychiatrists who wanted to open up the closed asylum system by integrating institutional and social-psychiatric care for the insane in the broader field of public mental health care, failed to realize their goal, also because of financial policies. If the Dutch Ministry of Domestic Affairs co-ordinated the country's public mental asylums, which were not funded and administered as health care but on the basis of the poor relief effort and the judicial requirements of institutionalization, the mental hygiene facilities fell under the aegis of the health section of the Ministry of Social Affairs. A new umbrella organization, the National Federation of Mental Health, was established in 1934 to maintain contacts with the health section of the Ministry of Social Affairs and distribute public health funds. In part because of Lekkerkerker's influence, most funding went to the Child Guidance Clinics while most pre-care and after-care facilities were excluded because they were the responsibility of the Ministry of Domestic Affairs as part of its responsibility for monitoring care of the insane. ${ }^{14}$ Many psychiatrists felt that Lekkerkerker's concept of prevention was an overly one-sided interpretation of mental hygiene which left the insane out in the cold. On the eve of the Second World War, the competing views on what belonged to mental hygiene and what not caused a split between asylum psychiatry and mental health care, with pre- and after-care hovering uneasily in between.

\section{Expansion and Professionalization (1945-1983)}

During and after the war the National Federation of Mental Health attempted to reorganize and unify the fragmented Dutch mental health care system. In addition to proposing more governmental supervision and funding, some psychiatrists favoured a closer link between institutional and outpatient care and more collaboration among the various ambulant facilities. Apart from the pre- and after-care services and Child Guidance Clinics, two separate Institutes for Psychotherapy and a growing number of Centres for Marriage and Family Problems were set up in the 1940s. ${ }^{15}$ Querido and other social psychiatrists strongly advocated an integrated mental health care system, in which social psychiatry would play a pivotal role as an intermediary between the mental asylums and psycho-hygienic provisions. ${ }^{16}$ Again others rejected such proposals: they favoured a strict separation between intramural psychiatry and extramural mental hygiene, not just because of the stigma associated with the insane, but also because in their opinion mental hygiene comprised much

\footnotetext{
${ }^{13}$ De Goei, op. cit., note 11 above, pp. 69-102.

${ }^{14}$ Inspectie van het staatstoezicht op krankzinnigen en krankzinnigengestichten, op. cit., note 6 above, pp. $20-1$.
}

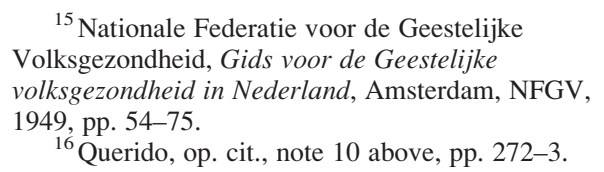




\section{Social Psychiatry in The Netherlands, 1916-2000}

more than just medical psychiatry. Much like the 1930 Washington conference, the 1948 international meeting of the World Federation of Mental Health in London provided a major incentive to the Dutch psycho-hygienic movement. The notion "mental health" replaced "mental hygiene" so as to underscore that not only prevention, treatment, and curing of mental problems mattered, but also that it was important to ensure maximal health and general well-being for all citizens. The National Federation of Mental Health focused on developments in Britain and America, where various psychosocial approaches pushed back the medical-psychiatric angle. The biomedical perspective was now definitively superseded by the view that education and environment (especially family life) constituted the main factors in the emergence of mental problems and disorders. Even more strongly than before, emphasis was put on the need for a multidisciplinary approach by teams of various nonhierarchical professional groups: psychiatrists, psychologists, pedagogues, psychiatricsocial workers, and social-psychiatric nurses. The psychoanalytic model, which was already central in Child Guidance Clinics, became more prominent, even though the commonest form of treatment in outpatient services was more akin to social casework and counselling. From the late 1940s the Dutch mental health care provisions expanded, received more government funding, and saw increased professionalization. Worries about social disruption and moral decay in the wake of the German occupation and liberation, followed by concern about the harmful psychosocial effects of economic modernization, offered psycho-hygienists a strong argument for their cause. Many people were unable to cope with social pressure and change, they argued, because of individual shortcomings, behavioural defects and difficulties with relationships; these were all treatable and could be prevented from degenerating into more serious mental disorders.

The 1950s, 1960s and 1970s saw a vast expansion of Child Guidance Clinics, Centres for Marriage and Family Problems, and Institutes for Psychotherapy, which catered to a clientele with a variety of psychic and behavioural problems. A psychological perspective and various talking-cures increasingly set the tone in these facilities. To be eligible for treatment, clients were expected to have some capacity for introspection, verbal talent, initiative and willingness to change, and this automatically excluded the mentally ill. ${ }^{17}$ The pre- and after-care services, which had barely survived the war but which were restored in the late 1940s, failed to win a solid footing in this new ambulatory mental health care network, although they employed more psychiatrists and served more patients than the other facilities. ${ }^{18}$ Whereas other outpatient facilities received grants from the health care Prevention Fund, social psychiatry was dependent on support from local and provincial governments, which provided money obtained after cutbacks in their financial contributions to the operation of mental institutions. Not until 1961, when the pre-care and after-care facilities were officially renamed as Social-Psychiatric Services, was their funding formally regulated on a national basis. On the other side, there was no close relationship between social and

\footnotetext{
${ }^{17}$ A de Swaan, R van Gelderen and V Kense, Sociologie van de psychotherapie 2: Het spreekuur als opgave, Utrecht, Antwerp, Het Spectrum, 1979, pp. 29-32; C Brinkgreve, J H Onland and A de Swaan, Sociologie van de psychotherapie 1: De opkomst van het psychotherapeutisch bedrijf,
}

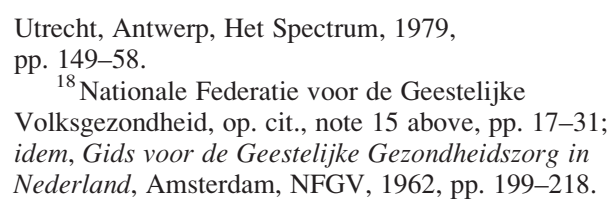




\section{Harry Oosterhuis}

institutional psychiatry. Because of the uneven regional spread of mental institutions, many of which admitted patients from their own constituency from all over the country, the psychiatric hospitals gradually gave up organizing pre-care and after-care services themselves, although many institutional psychiatrists worked part-time for them.

Nearly all Social-Psychiatric Services basically operated autonomously and their size and quality varied substantially. ${ }^{19}$ The public facilities in some large cities were equipped best. The provincial services, found in less densely populated regions, tended to be small; usually they employed just one part-time psychiatrist, who generally was not specially trained for the job, and a few full-time social psychiatric nurses. Among psychiatrists, social psychiatry held little prestige, because of the high pressure of work and the irregular shifts, and also because officially psychiatrists were not allowed to give patients medical treatment. In fact, social psychiatry was social work rather than medicine. Because universities devoted little attention to this branch of psychiatry, it hardly attained academic status, which meant that in actual practice much of the work required pragmatism and a talent for improvisation. ${ }^{20}$ Psychiatrists kept office hours, and the social-psychiatric nurses, as the key players, either paid house visits or provided help to clients in collaboration with other care providing facilities and social institutions. The Social-Psychiatric Services not only catered for people with serious psychiatric symptoms, but also for feeble-minded children and adults, the demented elderly, epileptics, alcoholics, and so-called "psychopathic" delinquents on probation. For some patients, who had been discharged from hospital, but who could not live on their own, halfway houses were set up. The introduction of new psychopharmacological drugs in the 1950s, which allowed more patients to be treated at home, contributed to the growth of these services. In the 1960s, when psychologists began to work in this field, family and group therapy was introduced. Despite its marginal position in both intra- and extramural mental health care, social psychiatry expanded in the 1950s and 1960s. By the mid-1960s, nationwide there were as many as 186 treatment facilities run by thirty-four organizations, most of which originated in private initiatives. ${ }^{21}$

The fierce debates in the 1960s about the unfavourable effects of society on individuals, which became fused with the anti-psychiatry movement's critique of the medical institutionalization and treatment of the mentally ill, accentuated the contrast between intramural psychiatry and extramural mental health care. Despite the new therapeutic energy found in mental hospitals after the introduction of psychiatric drugs and other forms of treatment, and the significantly enhanced quality of care as a result of more funding, institutional psychiatry's reputation hardly improved. On the contrary, the anti-psychiatry movement caused its public image even to deteriorate, not so much because of the absence of sufficient medical forms of treatment, which had hampered psychiatric hospitals before the 1950s, but precisely because of the dominance of the medical regime. The anti-psychiatry movement

${ }^{19} \mathrm{~T}$ E D van der Grinten, 'Integratie en differentiatie in de geestelijke gezondheidszorg; het moeilijke evenwicht', in B P R Gersons, T E D van der Grinten, A J Heerma van Voss, W G J Iemhoff and J L Mulder (eds), In het spoor van Kees Trimbos: Denkbeelden over preventieve en sociale psychiatrie, Deventer, Van Loghum Slaterus, 1990, pp. 65-75, on pp. 66-7.

\footnotetext{
${ }^{20} \mathrm{H}$ Bakker, L de Goei and J Vijselaar, Thuis opgenomen: Uit de geschiedenis van de sociale psychiatrie in Nederland, Utrecht, Nederlands centrum Geestelijke volksgezondheid, 1994.

${ }^{21}$ Nationale Federatie voor de Geestelijke Volksgezondheid, Gids voor de Geestelijke volksgezondheid in Nederland, Amsterdam, NFGV, 1962, pp. 199-218.
} 


\section{Social Psychiatry in The Netherlands, 1916-2000}

aimed its guns at clinical psychiatry rather than mental health care as such. It argued for a better psychiatry, meaning a de-medicalized and de-institutionalized psychiatry in the community, much as it was found in the ambulatory mental health sector, which since the 1930s had repeatedly distanced itself from medical psychiatry and since the 1950s had largely a social-psychological orientation. Mental health workers, many of whom had no exclusively medical background but a psychological or sociological one, embraced some of anti-psychiatry's basic principles. Ultimately, the sixties' movement and anti-psychiatry led to more, rather than fewer, mental health care services: supported by the expanding and generous welfare state as well as leftist policies, the facilities that offered psychosocial and psychotherapeutic treatments increased in both size and number throughout the $1970 \mathrm{~s} .{ }^{22}$ In the early 1970s the number of patients who received treatment in extramural care facilities surpassed the number of admissions to psychiatric hospitals and clinics. However, this eventful era did not constitute a break in the basic development of the history of twentiethcentury mental health care in the Netherlands. Dissatisfaction with psychiatry as practised in mental institutions (and also its unacknowledged impotence to treat serious and chronic mental illness) invariably prompted the expansion of the extramural professional mental health system, which attracted a steadily growing number of new clients.

The new mental health professionals revealed themselves as inspired advocates of personal liberation in the areas of religion, morality, relationships, sexuality, birth control, education, work, and drugs, as well as supporting the emancipation of women, youngsters, the lower classes, traumatized war victims, and other disadvantaged groups like homosexuals and ethnic minorities. Influenced by the welfare ideology, the prevention objective-which motivated the mental hygiene movement from the start-received a boost as well as a broader interpretation. Many psychotherapists and social workers were not much involved in the treatment of the mentally ill; rather, they focused on the improvement of people's psychosocial welfare, their self-development opportunities, social participation, and assertiveness. The 1970s were the heyday of psychotherapy, which was practised by psychiatrists as well as psychologists and social workers; in the public mind it constituted the pars pro toto of mental health care. Not only did the number and size of the psychotherapeutic institutes grow, but various psychotherapeutic approaches were also applied in other ambulatory facilities and private practices. A growing number of people began to consider it self-evident to seek psychotherapeutic help for all sorts of mental discomfort. Both therapists and clients viewed themselves as a cultural avant-garde: psychotherapy would liberate individuals from unnecessary inhibitions and provide them with opportunities for self-discovery, self-confidence and personal growth. Most clients had a middle-class background: they tended to be young, well-educated, nonchurchgoing, and studying or professionally active in service-sectors like health care, social work, and education. ${ }^{23}$

\footnotetext{
${ }^{22}$ Idem, Gids voor de Geestelijke Gezondheidszorg in Nederland, Amsterdam, NFGV, 1965, pp. 20-40, 59-64, 68-75, 241-52; Nationaal Centrum voor Geestelijke Volksgezondheid, Gids Geestelijke Gezondheidszorg 1981, Utrecht, NCGV, 1982, pp. 43-241; D Ingleby, 'The view from the North Sea',
}

in M Gijswijt-Hofstra and R Porter (eds), Cultures of psychiatry and mental health care in postwar Britain and the Netherlands, Amsterdam, Atlanta, Rodopi, 1998, pp. 295-314.

${ }^{23}$ Brinkgreve, Onland and De Swaan, op. cit., note 17 above, pp. 97, 104, 124. 


\section{Harry Oosterhuis}

What did all of this mean for the social-psychiatric care of the mentally ill? Although the Social-Psychiatric Services also expanded as a result of more lavish funding and a growing number and variety of professional workers, they clearly stood on the defensive vis-à-vis other mental health care facilities, as was apparent in the prolonged debates about their merging into Regional Institutes for Ambulatory Mental Health Care (RIAGG), modelled after the American community mental health centres. Psychiatrists and other mental health workers were deeply divided on the question of what direction the planned RIAGG system should take. The psychotherapeutic institutes, as well as the Centres for Marriage and Family Problems and the Child Guidance Clinics, distanced themselves once again from care provision for psychiatric patients, emphasizing their identity as welfare facilities with a psychotherapeutic orientation. ${ }^{24}$ Workers in social psychiatry as well as in outpatient clinics for alcohol and drug addicts, on the other hand, feared that their patients would receive less attention in a new organization that mainly focused on approachable and treatable clients and which kept chronic, serious or unmanageable mental patients at bay. According to this reasoning, the new system would allow if not cause "difficult" cases to slip through the net. The city-run Social-Psychiatric Services in large urban areas resisted integration into the new system until the very end, fearing that the accessibility or public character of social and emergency psychiatry would suffer. They mainly provided care to problem groups that were hard to approach, such as drug addicts and the homeless, who in addition to psychiatric problems also had physical and social problems, who generally did not ask for help on their own initiative, and were shut out from other forms of care, but caused trouble and social inconvenience. ${ }^{25}$ Ultimately, the social-psychiatric facilities, in contrast to the outpatient clinics for alcohol and drug addicts, merged into the RIAGG system, which was implemented in 1982. Two key factors triggered its emergence: pressure from the government, which wanted to reinforce the ambulatory sector as a counterbalance to institutional psychiatry, and the growing need to control rising costs, the more so because the economic crisis in the second half of the 1970s revealed the limitations of the unbridled growth of the preceding years. ${ }^{26}$ The new system, which comprised various types of the caring and mental health professions, engaged in a range of activities-including care, treatment, counselling, prevention, advice, and emergency psychiatry - that were aimed at a broad spectrum of problems, from the existential to mental suffering and serious psychiatric disorders. The almost sixty facilities of the RIAGG system had a regional basis, evenly spread throughout the country and each covering a catchment area of between 150,000 and 300,000 residents. While psychiatrists had often played a leading role in

\footnotetext{
${ }^{24}$ Nationale Federatie voor de Geestelijke Volksgezondheid, 1965, op. cit., note 15 above, p. 241; A A Fischer, 'De ontwikkeling van de psychotherapie in de instituten voor psychotherapie', Nederlands Tijdschrift voor Psychiatrie, 1970, 12 (2-3): 41-57, p. 44; M A J Romme (ed.), Voorzieningen in de Geestelijke Gezondheidszorg: Een gids voor consument en hulpverlener, Alphen aan den Rijn, Brussels, Samson Uitgeverij, pp. 32, 120; Nationaal Centrum voor Geestelijke Volksgezondheid, op. cit., note 22 above, p. 17; C Willemsen, De belofte van het hiernumaals: Zeventig jaar ambulante geestelijke
}

gezondheidszorg in het gewest Breda 1929-1999, Nijmegen, SUN, 2001, pp. 228-9.

${ }^{25}$ B P R Gersons, 'Acute psychiatrie in Amsterdam: verleden of toekomst?', Maandblad Geestelijke volksgezondheid, 1983, 38: 252-64; J C van der Stel, Drinken, drank en dronkenschap: Vijf eeuwen drankbestrijding en alcoholhulpverlening in Nederland, een historisch-sociologische studie, Hilversum, Verloren, 1995, pp. 406, 427.

${ }^{26} \mathrm{~T}$ Festen, et al., Van dichtbij en veraf: 15 jaar RIAGG / 25 jaar NVAGG, Utrecht, NVAGG, 1997, pp. 57,82 . 


\section{Social Psychiatry in The Netherlands, 1916-2000}

the older facilities, this was no longer evident in the multidisciplinary RIAGGs, in which they constituted a minority among psychologists, social-psychiatric nurses, social workers, and other professionals.

\section{Socialization of Mental Health Care (1983-2000)}

After the RIAGG was created critics soon argued that it was geared towards the wrong clientele, namely individuals with minor psychosocial problems and psychological disorders, a group that in fact constituted the target group of psychotherapists. Mental health care, some claimed, had to concentrate on marginal groups that were not so pleasant to deal with, but that really were in need of care: those who suffered from serious and chronic mental disorders hard to treat, and those with serious behavioural problems who were troublesome and potentially aggressive. In the previous decades, these patient categories had been rather neglected by the leading outpatient facilities because they did not fit their optimistic therapeutic model. Now, social psychiatry, which had never been prominent in the ambulatory sector, would have to become a priority. In the 1980s and 1990s, the government repeatedly argued the need for shifting attention away from those with minor afflictions to those with serious disorders, not only to stem the growing demand for mental health care, but also to reduce admissions to mental hospitals. After the 1980s, the isolation and large size of psychiatric hospitals were broken down, and outpatient and semimural facilities, like sheltered housing, expanded. Increasingly, psychiatric patients lived and worked outside treatment facilities, so as to advance their social integration. The number of long-term admissions dropped significantly because of this process. Only people with serious mental problems who were unable to get by in society on their own without hurting either others or themselves were eligible for temporary hospitalization. All other psychiatric patients, including those with chronic afflictions, should receive the help they needed from extramural provisions, including, apart from the RIAGG system, psychiatric home care, day care treatment, crisis intervention, mobile psychiatric task force, outpatient psychiatric clinics, and special shelter and housing projects.

This policy, which prioritized social psychiatry, was again partly motivated by financial concerns, as outpatient care was supposed to be cheaper than hospitalization. It also echoed some of the ideals of the anti-psychiatry movement: the need to counter the social isolation of psychiatric patients, improve their autonomy, and respect their civil rights. The government's mental health policy of the 1980s and 1990s-termed "socialization"-meant a break with the historically developed constellation of Dutch mental health care, which since the 1930s had been marked by a sharp division between clinical psychiatry and the outpatient facilities. The socialization of mental health care required collaboration between extra- and intramural facilities, as well as between the mental health sector and adjacent sectors like welfare work, the care for drug and alcohol addicts, special housing, and the justice sector. In the late 1990s, to improve the co-operation between psychiatric hospitals and the RIAGGs in particular, the government pressured these organizations to merge at a regional level. Both the outpatient facilities and the psychiatric hospitals were replaced as separate organizations by so-called "care circuits" and "multifunctional units" for specific categories of patients, and "case-management" for individuals. This signified the emergence of a new organizational principle in mental health care, its basic principle no longer 


\section{Harry Oosterhuis}

being the supply of care by a number of separate institutions, but the constantly changing task and functions that had to be performed for various client groups.

This recent break in the government's dominant mental health policy, however, should not keep us from discerning the high level of continuity in the development of the Dutch mental health care sector. First, in contrast to the situation in the United States, Britain and Italy, large-scale and radical de-institutionalization did not happen. Despite protests, new psychiatric hospitals, aimed at downscaling and a more even regional spread, were built. After a small drop in the number of beds in psychiatric hospitals in the years 1975-85, the number grew slightly in the ensuing decade. ${ }^{27}$ Polarization and a radical break were averted by gradually integrating new practices in existing institutional frameworks. Second, in light of the government's persistent effort to shift the attention away from psychosocial problems and toward psychiatric disorders, it is questionable to what degree this shift was in fact realized. After all, the prevailing approach of the RIAGG network basically followed that established earlier by the Child Guidance Clinics, the Centres for Marriage and Family Problems, and the Institutes for Psychotherapy. They focused on psychosocial problems and psychotherapeutic forms of treatment, which staff members seemed to value more highly than medical and social-psychiatric activities. Although the 1970s euphoria about psychotherapy receded and the biomedical approach advanced in psychiatry, the number of people who received psychotherapeutic treatment doubled in the 1980s and 1990s. Funding continued to facilitate broad accessibility, and the number of psychotherapists increased as well. The RIAGGs, like the psychiatric outpatient clinics, continued to treat many individuals with more or less serious psychosocial problems. ${ }^{28}$ Only as the 1990 s evolved, did they begin to give priority to more serious psychiatric disorders and to their social-psychiatric tasks.

In close association with the dichotomy between minor psychosocial complaints and serious psychiatric problems, the reach and accessibility of the mental health sector continued to be an issue of debate. In response to the pleas of politicians as well as of some psychiatrists to discourage the still growing demand for mental health care, others replied that the mental health sector, in contrast to somatic medicine, was still not given a generous share and that therefore a further expansion could well be justified. Either way, between 1980 and 2000 the growth of the mental health care sector, which since the mid-1960s had been facilitated through its funding by the national social and health insurance system, continued. The total number of individual registrations - not the same as the number of individual patients or clients as some of them may register several times or at different facilities - went up from 26.6 per thousand residents in 1980 to 69.2 in 1997, or from an annual total of some 380,000 to over a million. In the mid-1990s, about 5 per cent of the Dutch population, or between 700,000 and 750,000 people, came into contact with the mental health care system, while 4 per cent was actually accepted for treatment. ${ }^{29}$ The large

\footnotetext{
${ }^{27}$ M A J Romme, 'Deïnstitutionalisering in de psychiatrie; een emancipatieproces', in Gersons, et al. (eds), op. cit., note 19 above, pp. 35-47, on p. 44.

${ }^{28}$ F Lemmens, J van Busschbach, D de Ridder and P van Lieshout, 'Psychotherapie in de RIAGG: een balans', Maandblad Geestelijke volksgezondheid, 1990, 45 (4): 356-72; see also the article of Giel Hutschemaekers and Harry Oosterhuis in this issue.
}

\footnotetext{
${ }^{29}$ G Hutschemaekers, 'Wordt Nederland steeds zieker? Kerngetallen en achtergrondanalyses', Maanblad Geestelijke volksgezondheid, 2000, 55: 314-35, pp. 316-17; P Schnabel, De Geestelijke gezondheidszorg: goed voor verbetering voortgaan met het vernieuwingsbeleid, Utrecht, Nationaal Fonds Geestelijke Volksgezondheid, s.a., p. 9.
} 
majority of them, around 80 per cent, were treated in outpatient facilities, the RIAGGs in particular.

Under the influence of the ongoing expansion of care consumption in the 1990s, attention to the social dimension of psychic disorders and their possible prevention increased and a familiar cultural pessimism resurfaced. The rise in mental disorders was thought to be generated by the pace and intensity of social change, social fragmentation, the loss of normative and meaningful frameworks, a lack of a sense of security, and the extreme demands that were made on people in terms of flexibility, social skills, and mental resilience. The optimistic view espoused by many mental health workers in the 1970s that emancipated and motivated individuals would solve society's problems in a harmonious way, was replaced by concern for the loss of a sense of community and public morals, and the fear that the individual freedom of one person might well conflict with that of another. ${ }^{30}$ Furthermore, the positive evaluation of self-determination began to be questioned, since it allowed mentally ill individuals to refuse psychiatric treatment, even if they caused social trouble or could not take care of themselves. Pleas for more pressure and coercion in socialpsychiatric care, for a new form of public mental health care under the government's authority and for new experiments in special outreach care for those in particular problem groups put earlier ideals of individual liberty and self-development into perspective.

\section{Dutch Social Psychiatry: Basic Characteristics and Trends}

The initiatives of the 1920s in the area of pre-care and aftercare services were closely bound up with mental institutions and their problems. This new form of care was in part an effort to break with the obsolete tradition of institutional psychiatry and renew it. In the 1930s representatives of the psycho-hygienic movement embarked on a different course, which in time became the dominant one. The mental health sector began to define its role and identity by distancing itself from institutional psychiatry and by stressing that its client groups had little to do with the insane. After the Second World War, the Child Guidance Clinics, the Centres for Marriage and Family Problems, and the Institutes for Psychotherapy set the tone, while social psychiatry and also the clinics for alcohol and drug addicts were pushed into the background. In the early 1980s social psychiatry was formally integrated into the RIAGG network, but the persistent critique that these did not devote sufficient attention to psychiatric patients with serious disorders suggested that the radical split between hard-core psychiatry and the psychosocial mental health sector still existed. The latest developments, pressured by the government, suggest that, finally, clinical psychiatry and outpatient care will become fully integrated, as a result of a planned merger between the various intramural, semimural, and extramural organizations.

It is hard to ignore the impression that there has been a strong tendency in Dutch ambulatory mental health care to keep patients with serious psychiatric disorders-who may be bothersome, annoying, dangerous, or frightening to others and difficult to treat —out of its system. In this respect, it followed a long tradition within psychiatry as a whole: the recurrent alternation and juxtaposition of therapeutic optimism and pessimism. Time and

\footnotetext{
${ }^{30} \mathrm{P}$ Schnabel, R Bijl and G Hutschemaekers, Geestelijke volksgezondheid in de jaren'90: Van ideaal
}

tot concrete opgave, Utrecht, Nederlands centrum Geestelijke volksgezondheid, 1992, p. 38. 


\section{Harry Oosterhuis}

again, experts argued that the existing facilities fell short in providing adequate treatment to patients, let alone in curing them. Yet this observation almost never led to the conclusion that psychiatry or mental health care itself was fundamentally flawed. The belief prevailed that alternative ways of organizing care and establishing new facilities would lead to success where previous efforts had failed. Repeatedly, newly established facilities caused an expansion of psychiatry and mental health care, as well as the emergence of new groups of patients, and a distinction made between those who were treatable and those who were not. This frequently implied that attention for the former led to the neglect of the latter.

Around 1900, increasing doubts were raised about the beneficial effects of a patient's stay in a closed asylum. As a result, therapeutic optimism began to be oriented towards other facilities: the specialized sanatoriums and clinics for alcoholics and patients with nervous disorders, private practices, and mental wards and hospitals where acute and "neurotic" patients were admitted and treated on strictly medical grounds, without certification. From a therapeutic perspective, however, the partly open and partly closed institutions for the mentally ill continued to be a source of concern, especially given their overcrowding with chronic cases. In the 1920s, this therapeutic pessimism led to new facilities for psychiatric patients, the pre-care and after-care services for people who no longer had to be hospitalized, or did not yet have to be, and to the psycho-hygienic effort to prevent mental disorders. This second objective caused a substantial expansion of psychiatry's domain: children and youngsters with learning, educational, and developmental problems were now potentially included, as were adults with problems in the spheres of marriage, family, relationships, procreation, sexuality, alcohol addiction, and work. From the 1960s, mental health expanded to include welfare and individual well-being as well: to a large extent psychotherapy catered to individuals who were basically healthy but who nevertheless were troubled by personality flaws, relational problems, existential uncertainty, and their potential for self-development. Only from the mid-1980s, partly because of financial considerations, was the continuing expansion of the mental health sector questioned more often and attention focused again on the seriously and chronically mentally ill.

The strong growth of the ambulatory sector, especially after 1970, might give the impression that ever larger numbers of Dutch suffered from mental afflictions. This, however, is hard to substantiate. There are indications that there is no correlation between the incidence of mental suffering in a population and the degree to which its members make use of care facilities. Studies from the 1980s and 1990s reveal that in every year about one quarter of the adult population between the ages of eighteen and sixty-four suffered from a psychiatric disorder or serious psychosocial problem listed in the Diagnostic and statistical manual of mental disorders (DSM). Although this number was significantly higher than that of persons who ended up in the mental health system (which increased from over 2 per cent to almost 5 per cent of all adults), it remained steady over the years and was similar to that of many other countries. ${ }^{31}$ These data on mental suffering cast doubt on the view that the

${ }^{31} \mathrm{R}$ V Bijl, G van Zessen and A Ravelli, 'Psychiatrische morbiditeit onder volwassenen in Nederland: het NEMESIS-onderzoek. II, prevalentie van psychiatrische stoornissen', Nederlands Tijdschrift voor Geneeskunde, 1997, 141 (50): 2453-60; H J Wennink, De ongelukkige relatie tussen maatschappij en geestelijke gezondheidszorg: Een bezinning op 25 jaar rumoer in de (sociale) psychiatrie, Maarssen, Elsevier, De Tijdstroom, 1998, p. 77; Schnabel, op. cit., note 29 above, pp. 10, 13; Hutschemaekers, op. cit., note 29 above, p. 317. 


\section{Social Psychiatry in The Netherlands, 1916-2000}

population's growing demand for care also reflected an increase in mental disorders and problems. For one thing, it suggests that many with mental problems did not look for professional care and that family physicians considered only a portion of the complaints they identified as serious enough for referral to mental health services. It cannot be denied, however, that between 1980 and 2000 more and more individuals found their way to a mental health facility, especially in the ambulatory sector: there was in fact a doubling in the number of registrations. ${ }^{32}$

Social and cultural factors have probably had greater influence on the size of care consumption than the measure in which mental suffering actually took place or not. With psychosocial problems, to which a large segment of the outpatient facilities were geared, the definitions of disorders tended to change and expand. The way in which individuals experienced them, dealt with them, and looked for ways of solving them was subject to change during the twentieth century. Existential problems remain, but their specific interpretation as mental health problems has been strongly determined by the availability and familiarity of specialized services, of specific treatment opportunities, and of the psychological discourse used by experts. These rendered a host of problems visible and identifiable, and, most importantly, offered a context for talking about them. Social arrangements influenced what counted as a problem, what complaints were signalled and discussed, and who was asked to treat them. ${ }^{33}$ In the psychosocial and psychotherapeutic mental health sector the growing supply of professional care created an increasing demand for care, rather than the other way around. In contrast, institutional and social (preand after-care) psychiatry focused on individuals suffering from serious forms of mental disease, like schizophrenia, manic depression, dementia, or autism-expressions and behaviours that go against the commonly shared social patterns of mutual trust and expectations. If social constructivism can account for the development of mental health care at all, this applies to the segment that focuses on psychosocial problems rather than on what remains the heart of the psychiatric domain: the core group of severely mentally ill individuals-a group the relative size of which has remained fairly stable over time. ${ }^{34}$

Social psychiatry in the Netherlands has been sandwiched between institutional psychiatry for the mentally ill and services for patients with less serious psychosocial problems. Although pre- and after-care, and later on Social-Psychiatric Services, steadily grew into an essential psychiatric sector, their public reputation was surpassed by that of the other mental health facilities and they were hardly in a position to take a stand against the bastion of the psychiatric hospitals. For a long time, social psychiatry was on the defensive. Ironically, this was reinforced by the early and continuous development of a wide range of psycho-hygienic and psychosocial facilities. Their psychosocial and psychotherapeutic orientation was in part accounted for by the strong differentiation, from the 1930s until the mid-1980s, between clinical psychiatry in asylums and hospitals on the one hand and the mental hygiene and health sector on the other. Especially from the 1960s, the psychological approach and the prestige of psychotherapy contributed to a situation where many mental health experts in

\footnotetext{
${ }^{32}$ Hutschemaekers, op. cit., note 29 above, p. 317.

${ }^{33}$ Brinkgreve, Onland and De Swaan, op. cit., note 17 above, pp. 22-3; De Swaan, Van Gelderen and Kense, op. cit., note 17 above, p. 20.
}

\footnotetext{
${ }^{34} \mathrm{P}$ Schnabel, Het recht om niet gestoord te worden: Naar een nieuwe sociologie van de psychiatrie, Utrecht, Nederlands centrum Geestelijke volksgezondheid, 1992.
} 


\section{Harry Oosterhuis}

extramural care focused their attention on psychosocial problems rather than on psychiatric disorders. In other European countries public mental health provisions were more exclusively geared towards psychiatric patients, while there was also a closer link with the domain of clinical psychiatry, and psychotherapy largely remained limited to the more or less élitist private practices of psychiatrists. ${ }^{35}$ In some sense, developments in the Netherlands were more similar to those in the United States than to those in its neighbouring countries. In both the United States and the Netherlands the emphasis on a multidisciplinary approach in ambulant mental health care during the second half of the twentieth century ultimately resulted in both the expansion of its domain and a strong psychotherapeutic orientation. In the 1970s and 1980s there was a clear parallel between the development of the American community mental health centres and the various Dutch mental health provisions and, later, the RIAGG system. ${ }^{36}$

All of this should not blind us, however, to an important difference between the Netherlands on the one hand and the United States as well as Britain and Italy on the other. As in other European countries such as Germany and France, in the Netherlands de-institutionalization (often called "socialization") was pursued gradually. The gap between reforming ideals and their implementation was smaller in the Netherlands than in Italy, Britain, and the United States in particular. In recent years there has been an increase in more or less neglected psychiatric patients roaming the streets or living in private boarding houses in the Netherlands, but the outpatient system functions better than in many other countries, where entirely new community mental health structures had to be set up that were often scarce and understaffed. ${ }^{37}$ From the 1920 s, a network of socialpsychiatric facilities had developed in the Netherlands. The strong presence of private initiative in this field, in combination with generous funding by the Dutch welfare state since the 1960s, guaranteed organizational continuity. Partly because of this continued presence, it was possible to set up a variety of intermediate community care facilitiessituated halfway between the domain of the psychiatric hospitals and the realm of everyday life- to take care of patients for whom previously there was no alternative beyond institutionalization.

\footnotetext{
${ }^{35} \mathrm{~S}$ P Mangen (ed.), Mental health care in the European Community, London, Sydney, Croom Helm, 1985.

${ }^{36} \mathrm{G} \mathrm{N}$ Grob, The mad among us: a history of the care of America's mentally ill, Cambridge, MA, and London, Harvard University Press, 1994, pp. 263-6; E Shorter, A history of psychiatry: from the era of the asylum to the age of prozac, New York, John Wiley, 1997, pp. 288-95; R Castel, F Castel and A Lovell,
}

\author{
The Psychiatric Society, New York, Columbia \\ University Press, 1982. \\ ${ }^{37}$ Shorter, op. cit., note 36 above, pp. 277-81; A \\ Scull, 'Social psychiatry and deinstitutionalization \\ in the USA', paper presented at the Anglo-Dutch- \\ German meeting on 'Social Psychiatry and \\ Ambulant Care in the Twentieth Century', 4-6 July \\ 2002, The Wellcome Trust Centre for the History \\ of Medicine.
}

